\title{
Growth response and cost benefits of growing pigs to different herbal-mix feed additives and weight asymmetry
}

*Njoku, C. P., Fasakin, O. A., Ayano, T. R., Aweda, F. T., Amaihian, O. O., Apata, S. D., Mobolaji O. O. and Fakokunde, E. O.

Department of Animal Production and Health,

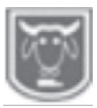

Abstract Federal University of Agriculture, Abeokuta, Nigeria

*Corresponding aauthor: njokucp@funaab.edu.ng; $+2348034647741,+2348023741145$

This study was carried out to investigate growth performance and cost benefits of growing pigs on different herbal-mix feed additives and weight asymmetry. Fifty-four, 8 weeks old Large White breed of pigs with an average body weight of $15.33 \pm 0.2 \mathrm{~kg}$ were randomly assigned to nine treatments with each treatment consisting of three replicates of two pigs each. Three diets containing different herbal-mix (Control diet without herbal-mix, moringa-basil meal diet, neem-basil meal diet) were formulated and fed to the pigs for sixteen weeks duration of the study. The moringa-basil and neem-basil leaf meals mixtures were in the ratio of 10 to 2 ; that is ten percent (10\%) moringa or neem to two percent $(2 \%)$ basil. Parameters determined include growth indices and cost benefits. Data collected were subjected to two-way analysis of variance using SAS (2000). Pigs on control diet had the highest final weight (49. 44, 43.22, $40.67 \mathrm{~kg})$ and daily weight gain $(515.87,401.59,388.89$ $\mathrm{g} / \mathrm{pig}$ ) and the best feed conversion ratio $(3.56,4.59,4.23)$ when compared to the values documented for pigs on ration containing different herbal-mix feed additives. The least total feed cost and revenue per pig were noted for pigs on neem-basil dietary treatment while the highest values were documented for pigs on control ration. Homogenous light weight pigs had higher feed intake and total feed cost per pigs when compared to other values noted for pigs on other treatment groups. Heterogeneous weight pigs recorded better feed conversion ratio, lower feed cost per kilogram weight gain and higher gross margin values when compared to the values noted for their homogenous counterparts. It can be concluded from this study that performance indices of growing pigs were affected by the dietary inclusion of herbal-mix feed additives and weight asymmetry. Hence, herbal-mix leaf meals can be integrated into growers ration in order to lower production cost, likewise, unevenly weight growing pigs can be managed together in order to obtain higher production efficiency in terms offeed intake and cost of production.

Keywords: Asymmetry, homogenous, herbal, feed additives, growth indices and production economy

\section{Introduction}

The resistance of antibiotic organism associated with the misuse of antibiotics in farm animals and the risk of transfer of antibiotic-resistant genes to human pathogens calls for attention. Restriction on the use of in-feed antibiotics in many countries has fuelled the interest in alternative products (Windisch, et al., 2008). Phytogenic feed additives are substances derived from plants. The consumption and demand for medicinal plants as phytogenic substances have been adopted in many countries because of low cost, easy availability, affordability for a common farmer, good antimicrobial ability, reduced diseases associated with risks, lowering blood cholesterol level and diversified functions in improving performance, growth rate, feed conversion rate and weight gain in domestic animals (Lewis et al., 2003). Probiotics were 


\section{Growth response and cost benefits of growing pigs}

developed as alternatives to the use of antibiotics as growth promoters, and incorporated in animal feed as a potential tool for reducing intestinal contamination with disease-causing and food-borne bacteria. Various plants parts and extracts have been studied for their antimicrobial abilities (Griggs and Jacob, 2005).

The practice of mixing unfamiliar and uneven weight groups of pigs may result to high incidence of aggressive behaviour which may affect the growth rate and compromise carcass yield and quality due to physiological stress and pathological responses to the stimuli that may reduce the immunity of the pigs (Mench et al., 1990; Nakanishi et al., 1993; Arey and Edward, 1998). The magnitude of the aggressive behaviour exhibited between the individuals could be determined by the degree of familiarity and weight differences among the pigs (Bostami et al., 2015). Studies have been conducted in order to establish practical approaches in the management of this aggressive behaviour in pigs. The suggested approaches include the use of sedative drugs or other chemicals, putting them in neutral pens or masking their body odours (Bostami et al., 2015). Most of these measures proved abortive as aggression resumes at full peak when the acute effects of the agents disappeared. It can be hypothesized that homogenous weight pigs reared on weight group basis promotes welfare, improved management, reduces aggressive behaviours, and enhances growth rate, nutrient digestibility and carcass quality. To this, the present study was aimed at investigating the effects of herbal-mix feed additives as alternate in-feed antibiotic and weight asymmetry on growth parameters and economy of production of growing pigs.

\section{Materials and methods}

Experimental animals and management

The experiment was carried out at the Piggery Unit of the Teaching and Research Farms of the Federal University of Agriculture, Abeokuta, Ogun State, Nigeria. The farm is geographically located within the rainforest zone of South Western Nigeria on latitude 7013' $\mathrm{N}$ and Longitude $3026 \mathrm{E}$ and altitude $76 \mathrm{~m}$ above sea level. The climate is humid with a mean annual rainfall of $1037 \mathrm{~mm}$. the annual mean temperature and humidity are usually $34^{\circ} \mathrm{C}$ and $82 \%$, respectively (Google Earth, 2018).

\section{Experimental pigs and management}

Fifty four Large White breed of growing pigs with a body weight range of 14.44 $16.22 \mathrm{~kg}$ were bought from a commercial farm within Abeokuta metropolis. The pigs were grouped based on their body weight into nine treatment groups with three replicates of two pigs per replicate. Two pigs serving as a replicate were housed together in a naturally ventilated pen with floor dimension of $4 \mathrm{~m}$ by $3 \mathrm{~m}$, equipped with concrete feeding and drinking troughs. Routine management practices were done on daily basis, with fresh water supplied ad libitum throughout the experimental period. Treatments one, two and three consist of homogenous heavy weight pigs fed basal diet that had no herbal-mix, diets containing moringa-basil and neem-basil leaf meals respectively, while those on treatments four, five and six were homogeneous light pigs on diets containing no herbal-mix, moringa-basil and neembasil leaf meals, respectively. Those in treatments seven, eight and nine were heterogeneous weight pigs offered daily ration that contained no herbal-mix feed additives, moringa-basil and neem-basil leaf meals, respectively. The composition and analysed nutrients of the experimental diets are shown in Table 1. 


\section{Njoku, Fasakin, Ayano, Aweda, Amaihian, Apata, Mobolaji and Fakokunde}

Table 1: Percentage composition of experimental diets of growing pigs

\begin{tabular}{|c|c|c|c|}
\hline Ingredients & Diet 1 (Control) & Diet 2 (Neem/ Basil) & Diet 3 (Moringa/ Basil) \\
\hline Maize & 50 & 50 & 50 \\
\hline $\mathrm{Pkc}$ & 10 & 10 & 10 \\
\hline Basil Leaf & 0 & 2 & 2 \\
\hline Moringa Leaf & 0 & 0 & 10 \\
\hline Neem Leaf & 0 & 10 & 0 \\
\hline Soya Bean Meal & 18 & 8 & 8 \\
\hline GNC & 9 & 7 & 7 \\
\hline Fish meal & 2 & 2 & 2 \\
\hline Wheat Offal & 6.9 & 6.9 & 6.9 \\
\hline Bone Meal & 3 & 3 & 3 \\
\hline Lysine & 0.3 & 0.3 & 0.3 \\
\hline Methionine & 0.25 & 0.25 & 0.25 \\
\hline *Premix & 0.3 & 0.3 & 0.3 \\
\hline Salt & 0.25 & 0.25 & 0.25 \\
\hline Total & 100 & 100 & 100 \\
\hline \multicolumn{4}{|l|}{ Calculated Analysis (\%) } \\
\hline Metabolizable Energy (Kcal/Kg) & 2834.59 & 2541.99 & 2805.9 \\
\hline Crude Protein & 20.90 & 18.87 & 17.60 \\
\hline Ether Extract & 4.56 & 4.84 & 4.49 \\
\hline Crude Fibre & 4.68 & 6.4 & 5.56 \\
\hline Ash & 3.05 & 3.54 & 3.1 \\
\hline
\end{tabular}

\section{Data collection}

\section{Growth performance}

Data were collected on daily feed intake and weekly weight gain of the growing piglets while feed conversion ratio was calculated. The initial weight of the animals was taken at the commencement of the experiment and subsequently on weekly basis to determine the change in their body weight. Weight gain $(\mathrm{g})=$ Final weight - Initial weight. Feed intake was determined by taking the difference between the quantities of feed offered to the animals and feed leftover. Feed Intake (g/day) = Feed offered - Feed leftover. While Feed conversion ratio was determined by relating the feed intake to the weight gained of the animals.

\section{Economic benefit analysis}

The prevailing market price of the ingredients at the time of study was used to calculate:
Cost per kg feed $=$

Summation of price per $\mathrm{kg}$ of feed ingredients $\mathrm{X}$ their proportion in the ration

$$
100
$$

* Feed cost per pig $=$ cost per $\mathrm{kg}$ feed $\times$ Quantity of feed consumed by the pig

Feed cost per weight gain $=$ Cost per $\mathrm{kg}$ feed $\times$ FCR

\&evenue per pig $=$ Price per kg live $\times$ Final live weight.

* Gross margin $=$ Revenue per pig - Feed cost per pig.

\section{Statistical analysis}

Data were processed by two-way analysis of variance using SAS (2000) package. Significantly $(\mathrm{p}<0.05)$ different means among variables were separated using New Duncan's Multiple Range Test as contained in the same package.

\section{Results}

The effect of diets containing herbal-mix 


\section{Growth response and cost benefits of growing pigs}

feed additives on growth performance of growing pigs is shown in Table 2. The final weight, total weight gain, daily weight gain, feed conversion ratio, feed cost per pig and revenue per pig were significantly $(\mathrm{P}<0.05)$ influenced by the dietary inclusion of herbal-mix. Diet without herbal-mix (control) had the highest $(\mathrm{P}<0.05)$ final weight, total weight gain and daily weight gain compared to those on other dietary treatment. Pigs fed diets containing Neembasil additives had the least $(\mathrm{P}<0.05)$ final weight value of $40.67 \mathrm{~kg}$. Pigs fed diets containing herbal-mix irrespective of type had a similar $(\mathrm{P}>0.05)$ total weight gain and daily weight gain. The feed conversion ratio of pigs fed control diet was better than those on diets containing moringa-basil. While pigs on neem-basil mix had a similar $(\mathrm{P}>0.05)$ feed conversion ratio compared to those on control and moringa-basil diets. The feed cost and revenue per pig were higher in pigs fed diets without herbal-mix additives when compared to those fed diet containing neem-basil leaf meal.

Table 2: Effect of herbal-mix feed additives on growth performance and cost benefits of pigs

\begin{tabular}{llll}
\hline Parameters & No herbal additives & Moringa-Basil additives & Neem-Basil additives \\
\hline Initial weight (kg) & $15.39 \pm 0.62$ & $16.22 \pm 1.02$ & $14.44 \pm 1.56$ \\
Final weight (kg) & $49.44 \pm 2.68^{\mathrm{a}}$ & $43.22 \pm 2.07^{\mathrm{ab}}$ & $40.67 \pm 1.81^{\mathrm{b}}$ \\
Total Weight gain $(\mathrm{kg})$ & $36.11 \pm 3.25^{\mathrm{a}}$ & $28.11 \pm 2.77^{\mathrm{b}}$ & $27.22 \pm 2.11^{\mathrm{b}}$ \\
Daily weight gain $(\mathrm{g})$ & $515.87 \pm 46.46^{\mathrm{a}}$ & $401.59 \pm 39.59^{\mathrm{b}}$ & $388.89 \pm 80.19^{\mathrm{b}}$ \\
Total feed intake $(\mathrm{kg})$ & $122.34 \pm 6.84$ & $120.12 \pm 6.93$ & $111.28 \pm 5.29$ \\
Daily feed intake $(\mathrm{kg})$ & $1.75 \pm 0.10$ & $1.72 \pm 0.10$ & $1.60 \pm 0.08$ \\
Feed conversion ratio & $3.56 \pm 0.31^{\mathrm{b}}$ & $4.59 \pm 0.47^{\mathrm{a}}$ & $4.23 \pm 0.27^{\mathrm{ab}}$ \\
Feed cost per pig ( & $19520 \pm 1090.61^{\mathrm{a}}$ & $17463 \pm 1007.40^{\mathrm{ab}}$ & $16206 \pm 770.46^{\mathrm{b}}$ \\
Feed cost $/ \mathrm{kg}$ weight gain & $568.74 \pm 49.23$ & $667.20 \pm 67.93$ & $616.06 \pm 38.68$ \\
Revenue per pig & $2472.22 \pm 1338.82^{\mathrm{a}}$ & $2161.11 \pm 1033.39^{\mathrm{ab}}$ & $2033.33 \pm 905.23^{\mathrm{b}}$ \\
Gross margin & $5202.00 \pm 1254.10$ & $4144.40 \pm 743.39$ & $4127.00 \pm 902.20$ \\
\hline ab & & &
\end{tabular}

${ }^{\mathrm{ab}}$ Means on the same row with different superscript are significantly different $(\mathrm{P}<0.05)$

The effect of weight asymmetry on growth performance and cost benefits of growing pigs is shown in Table 3 . The results obtained from the study indicated that weight asymmetry had significant $(\mathrm{P}<0.05)$ influence on initial weight, total feed intake, daily feed intake, feed conversion ratio, feed cost per pig, feed cost per kilogram weight gain and gross margin of the growing pigs. The initial weight was higher in homogenous heavy weight group compared to the statistically similar values documented for homogenous light weight and heterogeneous weight groups. The feed intake of homogenous heavy weight pigs and their heterogeneous weight counterparts was statistically similar but differed significantly $(\mathrm{P}<0.05)$ from the value noted for homogenous light weight grouped pigs. The homogenous weight groups (heavy and light weights) had similar feed conversion ratio values which was significantly $(\mathrm{P}<0.05)$ higher than the value documented for the heterogeneous weight group. Significantly higher cost of feed per pig was recorded for homogenous light weight pigs compared with the values obtained for homogenous heavy weight and heterogeneous weight groups that had comparable mean values. Homogenous heavy and light weights pigs had comparable feed cost per kilogram weight gain values that differed significantly from the value noted in the heterogeneous weight group. Homogenous heavy weight pigs and heterogeneous weight group had comparable gross margin mean values that were significantly higher than the value 
documented for homogenous light weight pigs. Other growth performance and cost benefit parameters considered in this present study were not significantly influenced by weight asymmetry.

Table 3: Effect of weight asymmetry on growth indices and cost benefits of growing pigs

\begin{tabular}{llll}
\hline Parameters & $\begin{array}{l}\text { Heterogeneous } \\
\text { weight }\end{array}$ & $\begin{array}{l}\text { Homogeneous light } \\
\text { weight }\end{array}$ & $\begin{array}{l}\text { Homogeneous heavy } \\
\text { weight }\end{array}$ \\
\hline Initial weight $(\mathrm{kg})$ & $13.83 \pm 0.57^{\mathrm{b}}$ & $11.00 \pm 1.08^{\mathrm{c}}$ & $18.22 \pm 1.02^{\mathrm{a}}$ \\
Final weight $(\mathrm{kg})$ & $47.00 \pm 2.23$ & $41.22 \pm 1.79$ & $45.11 \pm 3.04$ \\
Total weight gain $(\mathrm{kg})$ & $33.61 \pm 2.21$ & $30.21 \pm 2.65$ & $26.90 \pm 3.74$ \\
Daily weight gain $(\mathrm{g})$ & $480.16 \pm 31.54$ & $442.06 \pm 37.84$ & $384.13 \pm 53.37$ \\
Total feed intake $(\mathrm{kg})$ & $113.23 \pm 5.90^{\mathrm{b}}$ & $130.89 \pm 4.62^{\mathrm{a}}$ & $109.53 \pm 6.53^{\mathrm{b}}$ \\
Daily feed intake $(\mathrm{kg})$ & $1.62 \pm 0.08^{\mathrm{b}}$ & $1.87 \pm 0.07^{\mathrm{a}}$ & $1.57 \pm 0.10^{\mathrm{b}}$ \\
Feed conversion ratio & $3.41 \pm 0.13^{\mathrm{b}}$ & $4.39 \pm 0.23^{\mathrm{a}}$ & $4.59 \pm 0.52^{\mathrm{a}}$ \\
Total feed cost per pig $(\#)$ & $17030.97 \pm 967.10^{\mathrm{b}}$ & $19685.43 \pm 857.38^{\mathrm{a}}$ & $16468.87 \pm 1042.19^{\mathrm{b}}$ \\
Feed cost per kg weight gain $(\#)$ & $509.76 \pm 14.12^{\mathrm{b}}$ & $658.60 \pm 39.95^{\mathrm{a}}$ & $683.63 \pm 71.66^{\mathrm{a}}$ \\
Revenue per pig ( $)$ & $22560 \pm 1521.70$ & $19785 \pm 892.79$ & $21652.8 \pm 1139.57$ \\
Gross margin ( $)$ & $5525.00 \pm 351.83^{\mathrm{a}}$ & $100.70 \pm 253.21^{\mathrm{b}}$ & $5183.13 \pm 665.85^{\mathrm{a}}$ \\
\hline abc Means on the same row with different superscripts are significantly $(\mathrm{P}<0.05)$ different &
\end{tabular}

Table 4 shows the interactive effect of herbal-mix feed additives and weight asymmetry on growth performance and cost benefits of growing pigs. Initial weight, final weight, feed conversion ratio, feed cost per pig, feed cost per $\mathrm{kg}$ weight gain, revenue per pig and gross margin were significantly $(\mathrm{P}<0.05)$ influenced by the interactive effects of herbal-mix feed additives and weight asymmetry. Homogenous light weight pigs fed diet containing Neem-Basil leaf meal had the least final weight value $(\mathrm{P}<0.05)$ compared to the highest values obtained for homogenous heavy weight and heterogeneous weight pigs fed diet without herbal-mix. The homogenous heavy weight pigs on diets with no herbal-mix, heterogeneous weight pigs fed diets with no herbalmix additives and heterogeneous weight pigs fed diets containing neembasil feed additives had better feed conversion ratio compared to homogenous heavy weight pigs fed diets containing moringa-basil feed additive. The cost of feed per pig recorded for homogenous light weight fed diets without herbal-mix additive was significantly $(\mathrm{P}<0.05)$ higher than homogenous heavy weight pigs and heterogeneous weight pigs fed diets containing herbal-mix feed additives. The feed cost per weight gain was least $(\mathrm{P}<005)$ in heterogeneous weight pigs fed diets without herbal-mix feed additives. The highest $(\mathrm{P}<0.05)$ feed cost per weight gain was observed for homogenous heavy weight pigs fed diet containing with moringa-basil feed additive while those in other dietary treatments were statistically similar. Revenue per pig was highest on homogenous heavy weight pigs fed no herbal-mix feed additives while the same trend was also noticed on gross margin. 
Growth response and cost benefits of growing pigs

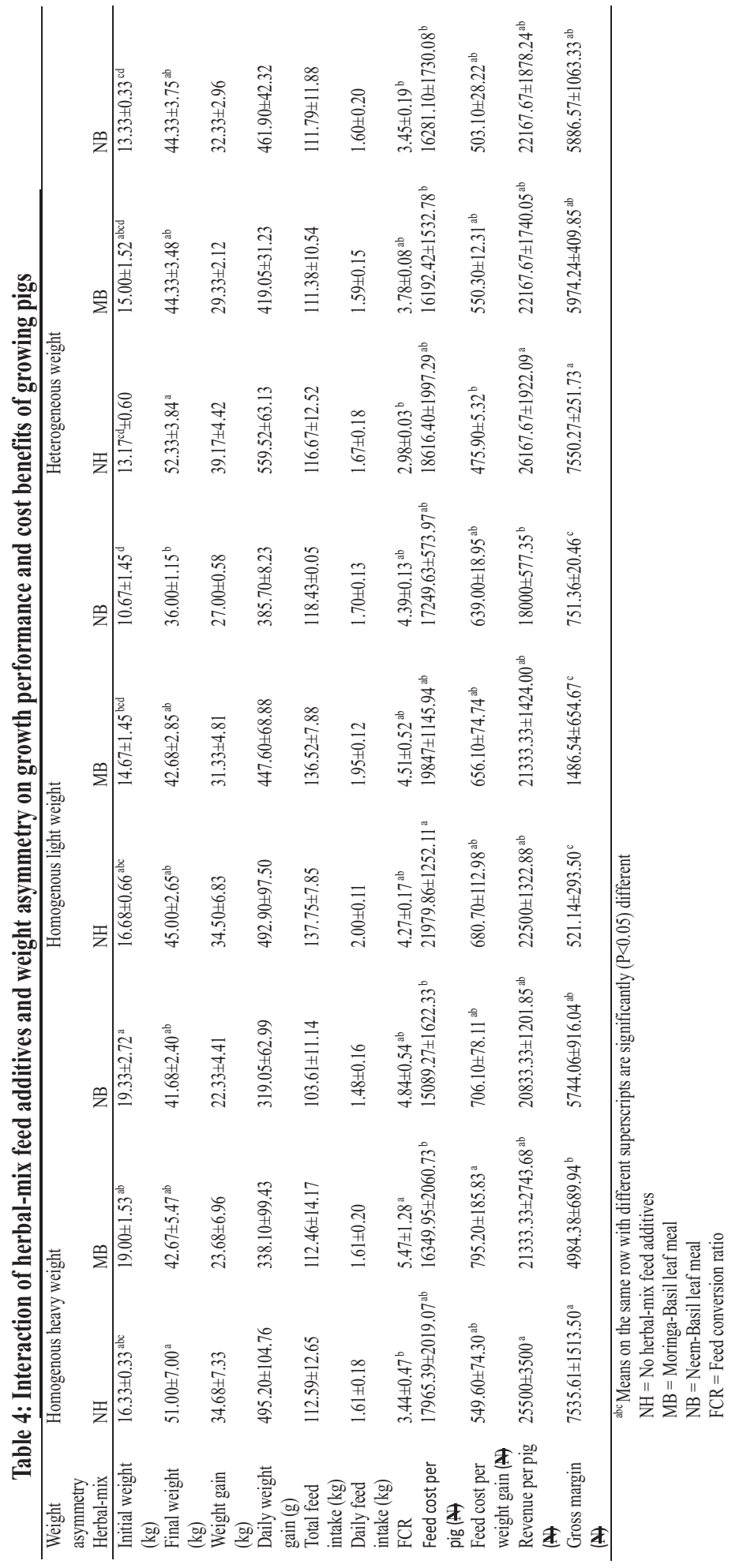




\section{Njoku, Fasakin, Ayano, Aweda, Amaihian, Apata, Mobolaji and Fakokunde}

\section{Discussion}

The decrease in final weight and total weight gain of pigs fed ration containing herbal-mix may be as a result of phytochemicals in the leaf meal used. Leaf meals are known to contain some chemical compounds such as phenols, tannins, oxalates, phytates, saponins, alkaloids and hydrocyanide (Isitua et al., 2015). Even though these chemical substances may have some health benefits, but they are reported to contain anti-nutrients (Nkukwana et al., 2014). These feed additives have been reported to reduce nutrient digestibility and efficiency of feed utilization. The anti-nutritive factor in the leaves used in this study may have resulted in the depressed growth recorded on pigs fed herbal-mix feed additives. Khachik et al. (1992) reported that the presence of phytates and other anti-nutrients can reduce the bioavailability of certain nutrients, thus depress growth. Ogbuewu et al. (2010) reported that different bioactive components of leaf meal may be irreplaceable for depression in nutrient utilization and growth of pigs at a higher level.

The non-significant effect of total feed intake and daily feed intake in all the dietary treatment suggested that the feeds were palatable and the pigs showed total acceptability irrespective of the dietary treatments. It is also suggested that the pigs were not motivated to consume more feed with the addition of herbal-mix. Voluntary feed intake has been enthused by $\mathrm{Mc}$ Donald et al. (1998) as a function of acceptability, palatability and utilization. Gwiazda et al. (1983) reported that feed deterrent, depressant reduce palatability and acceptability index. The nonsignificant of feed cost per kg weight gain in this study suggest that herbal-mix diets can be used to produce a similar result as the control diet. The high values of feed conversion ratio of pigs on a ration containing Moringa-Basil and Neem-Basil leaf meal suggested that the diets were poorly utilized by the pigs. This is evident in poor final weight gain observed in pigs on these dietary treatments. It's more expensive to raise pigs on the control diet even though the high revenue per pigs on control diet compensated for high cost of feed incurred on pigs fed control diet.

In pig production venture, selection of beneficial behaviours is essential for successful management, performance, profit maximization and overall pig welfare. Pig behaviour is the aggregate of pig actions and reactions in response to internal and external stimuli. In this present study, the growth performance data indicated that weight asymmetry influenced the initial weight, feed intake and feed conversion ratio of growing pigs. The significant difference noted in the initial weight of the growing pigs used in this present study resulted from the grouping method adopted, since individual pig to be selected as heavy weight must possess weight that should be significantly above the mean weight of the pigs at a certain age. The significant initial weight values with the homogenous heavy weight pigs commanding the highest value and the homogenous light weight pigs with the least value were cancelled out at final weight of the pigs which indicated that heterogeneous weight pigs had the highest numerical value compared to the values noted for pigs with uniform weights (heavy and light). The non significant final weight values could be linked to less aggressive behaviours (homogenous light and heterogeneous weight groups) that could have induced stress in the pigs leading to poor growth performance. The less aggression must have initiated better nutrient utilization in this set of pigs as observed in this present study. This present observation disagreed with earlier assertion 


\section{Growth response and cost benefits of growing pigs}

of Arey and Edward (1998), who concluded that the management of pigs with different weight together led to increased aggression that resulted to poor growth and reproductive performances of the pigs.

Likewise, it is in variance with the observation of Bostami et al. (2015) and Francis et al. (1996) that showed that weight gain of uniformly weight grouped pigs tends to be higher than their heterogeneous weight counterparts. Data from this present study indicated that homogeneous light weight pigs consumed more feed than homogenous heavy and heterogeneous weight pigs. The observed higher feed intake in the homogenous light weight pig that did not translate to better feed conversion ratio points to the facts that higher social and behavioural stresses occurred in this set of pigs as they could not evaluate the relative fighting ability of each other. Game theory model states that evenly matched opponents have difficulties with evaluating relative strength or fighting ability unlike with large weight differences (Anderson et al., 2000). The significantly better feed conversion ratio observed in heterogeneous weight pigs over the homogenous weight pigs is in variance with the study of Francis et al. (1996) that observed significantly lower feed conversion ratio in pigs with homogenous weight compared to the value documented for their heterogeneous weight counterparts.

The fight to ascertain a dominance hierarchy in the heterogeneous weight pigs must have been brief as the subordinate pigs easily appreciate the superiority of the pigs with higher body dimensions, leading to the better feed conversion ratio as less energy is invested in establishing this social order in the heterogeneous groups unlike the amount of energy investment in the homogeneous weight groups where prolonged fighting may have occurred.
Bostami et al. (2015) informed that the process in which social ranking occurs in group housed pigs is essential process since it has long run effect on productivity of the pigs. Economic analysis indicated that weight asymmetry had positive impact on total feed cost per pig, feed cost per weight gain, gross margin. English et al. (1988) found out that large group sizes of livestock resulted to high difficulty in management, increased aggression, potential loss of animal performance and impaired animal welfare. Heterogeneous weight group in this study had relatively lower feed cost, better feed cost per kilogram weight gain and higher gross margin; these must have resulted from improved productivity gotten from less agonistic behaviours. Although behavioural observation was not part of this study, there must have been an increase in the fighting behaviour in homogenous weight groups as the process of establishing ranking order must have been prolonged due to inability of the pigs to evaluate the fighting ability or strength of each other. Thereby, resulting to physiological stress that has detrimental effect on productivity and the amount of energy invested (Bostami et al., 2015; Cornea et al., 2006). Homogenous light weight pigs despite the fact that it consumed more feed than other groups had the least gross margin. The pigs must have utilized the extra energy intake in maintaining the level of physical activities involved in establishing social hierarchy rather than converting it into flesh.

\section{Conclusion}

The study showed that the herbal-mix feed additives impacted final weight, weight gain and feed conversion ratio, likewise, the cost analysis revealed that pigs on diet without herbal-mix feed additives had the highest feed cost and revenue per pig compared to the cost indices of pigs on different herbal-mix dietary treatments. 


\section{Njoku, Fasakin, Ayano, Aweda, Amaihian, Apata, Mobolaji and Fakokunde}

Weight asymmetry had positive impact on feed intake, feed conversion ratio, feed cost per $\mathrm{kg}$ weight gain and gross margin. Hence, the inclusion levels of the herbalmix additives should be reduced in order to enhance growth indices of pigs. While the application of weight asymmetry as one of the management tools in tropical pig production can serve as means of obtaining uniform slaughter weight rather than improving the productivity of growing pigs.

\section{References}

Anderson, I. I., Andenaes, H., Boe, K. E., Jensen, P. and Bakken, M. 2000. The effects of weight asymmetry and resources distribution on aggression in groups of unacquinted pigs. Applied Animal Behaviour Science 68:107-120

Arey, D. S. and Edward, S. A. 1998. Factors influencing aggression between sows after mixing and the consequences for welfare and production. Livestock Production Science 56(1): 61-70.

Bostami, A. B. M. R., Ahmed, S. T., Islam, M. M., Mun, H. S., Seung, Y. J. and Yang, C. 2015. Effect of weight asymmetry on growth performance, carcas s characteristics and economic analysis in pigs. Global Advanced Research Journal of Agricultural Science 4(1):006-016

Correa, J. A., Faucitano, L., Laforest, J. P., Rivest, J., Marcoux, M. and Gariépy, C. 2006. Effects of slaughter weight on carcass composition and meat quality in pigs of two different growth rates. Meat Science 72(1): 91-99.

English, P. R., Fowler, V. R., Baxter, S. and Smith, B. 1988. The growing and finishing pig: Improving efficiency. Farming Press Books,
Ipswich, pp. 331-373

Francis, D. A., Christison, G. I. and Cymbaluk, N. F. 1996. Uniform or heterogeneous weight groups as factors in mixing weanling pigs. Canadian Journal of Animal Science 76(2): 171-176.

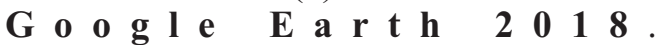
http://www.google.earth

Griggs, J. P. and Jacob, J. P. 2005. Alternatives to antibiotics for organic poultry production. Journal of Applied Poultry Research, 14:750-756

Gwiazda, S., Noguchi, A., Kitamura, S. and Saio, K. 1983. Effect of chlorogenic acid removal from leaf protein concentrate on fish feeding. Agricultural Biological Chemistry 47(3):623-625

Isitua, C. C., Sanchez-Muros, M. J., Jaramillo, L. C. and Dutan, F. 2015. Phytochemical and nutritional properties of dried leaf powder of Moringa oleifera Lam. from Machala el Oro Province of Ecuador. Asian Journal of Plant Science and Research, 5(2):8-16

Khachik, F., Goli, M. B., Beecher, G. R., Holden, J., Lusby, W. R., Tenorio, M. D. and Barrera, M. R. 1992. Effect of food preparation on qualitative and quantitative distribution of carotenoid constituents of tomatoes and several green vegetables. Journal of Agriculture and Food Chemistry, 40:390-398

Lewis, M. R., Rose, S. P., Mackenzie, A. M., Tucker, L. A. 2003. Effects of dietary inclusion of plant extracts on the growth performance of male broiler chickens. British Poultry Science 44(Suppl. 1): S43_S44.

McDonald, K. A., Penno, J. W., Kolver, 


\section{Growth response and cost benefits of growing pigs}

E. S., Carter, W. A., Lancaster, J. A. 1998. Balancing pasture and maize silage diets for dairy cows using urea, soybean meal or fish meal. Proceedings of the New Zealand Society of Animal Production, 58:102-105

Mench, J. A., Swanson, J. C. and Stricklin, W. R. 1990. Social stress and dominance among group members after mixing beef cows. Canadian Journal of Animal Science 70:345-354.

Nakanishi, Y., Kawamura, T. Goto, T. and Umetsu, R. 1993. Comparative aspects of behavioural activities of beef cows before and after introducing a stranger at night. Journal of Faculty of Agriculture, Kyushu University 37:227-238.

Nkukwana, T. T., Muchenje, V., Pieterse, E., Masika, P. J., Mabusela, T. P., Hoffman, L. C. and Dzama, K. 2014. Effect of Moringa oleifera leaf meal on growth performance of pig. Livestock Science 161: 139146
Ogbuewu, I. P., Uchegbu, M. C., Okoli, I. C. and Iloeje, M. U. 2010. Assessment of blood chemistry, weight gain and linear body measurements of pre-puberal buck rabbits fed different levels of neem (Azadirachta indica A. juss.) leaf meals. Chilean Journal of Agricultural Research, 70(3): 515-520.

S. A. S. Institute Inc. 2002. SAS/STAT User's Guide, Version 9.2. SAS Institute Inc., Cary, NC

Windisch, W., Schedle, E.O., K., Plitzner, C., Kroismayr, A. 2008. Use of phytogenic products as $\mathrm{f}$ e e d additives for swine and poultry. $J$. Anim Sci. 86 (suppl 14): E140E148

Received: $14^{\text {th }}$ August, 2018

Accepted: $21^{\text {st }}$ December, 2018 